\title{
Training Biology in English Language in Kazakhstani Education
}

\author{
Alibek Ydyrys ${ }^{1, *}$, Sayagul Srail ${ }^{2}$, Symbat Ydyrys $^{1}$, Zhandos Basygarayev $^{1}$, \\ Askar Mautenbaev", Tilek Baidaulet ${ }^{1,3,4}$ \\ ${ }^{1}$ Department of Biophysics and Biomedicine, Al-Farabi Kazakh National University, Kazakhstan \\ ${ }^{2}$ College of International Kazakh-Chinese language Academy, Kazakhstan \\ ${ }^{3}$ Department of Normal Physiology, Asfendiyarov Kazakh National Medical University, Kazakhstan \\ ${ }^{4}$ Methodical Association of Chemistry, Biology and Geography, №8 Yuriy Gagarin Talent Training Trilingual Education Special \\ Gymnasium, Kazakhstan
}

Copyright $C 2019$ by authors, all rights reserved. Authors agree that this article remains permanently open access under the terms of the Creative Commons Attribution License 4.0 International License

\begin{abstract}
A number of reforms were carried out in the educational system of the Republic of Kazakhstan in recent years, including education of natural sciences (biology, chemistry, and physics) in English at schools. This article will outline results of biology teaching in the school using different methods for the period of all 4 quarters (one academic year). Also, typical problems, obstacles that arise during the training of biology in English at the Kazakh schools are touched upon. At the end of the article, several suggestions are proposed for improving the quality of biology teaching in English.
\end{abstract}

Keywords Methodology of Biology Teaching, Education System of Kazakhstan, Teaching of Biology in English, Trilingual Training

\section{Introduction}

Kazakhstan is located in Central Asia, and it is the ninth largest country in the world by land surface, equivalent to more than twice the combined size of France, Germany and Poland. The country is bordered by Russia in the North, the Caspian Sea in the West, China in the South-East, Kyrgyzstan and Uzbekistan in the South, and Turkmenistan in the South-West. The population of Kazakhstan amounted to 17 million people in 2013. A big surface and small population result in a low density of population, which was estimated at 6.2 persons per square $\mathrm{km}$ in 2013 (IAC, 2014).

Population trends are not homogenous across the country: the northern areas are experiencing a decline while in the south there is a baby boom. East-Kazakhstan, Kostanay and Karaganda, North and West Kazakhstan, Akmola and Pavlodar have experienced population decreases in the period of 1999-2009, and North
Kazakhstan has seen its number of inhabitants reduced by $18 \%$. In contrast, the population has increased by more than $20 \%$ in the regions of Mangystau, South Kazakhstan and the cities of Astana and Almaty during this period. In 2013 , more than half of the population ( 9.4 million) lived in urban areas and an increasing trend towards urbanisation was observed (IAC, 2014). The most urbanized regions were Karaganda $(79 \%$ of urban population), Pavlodar (70\%), Aktobe (62\%) and East Kazakhstan (59\%). In contrast, the rural population was concentrated in Almaty (77\% of rural population), South Kazakhstan (61\%), Zhambyl (60\%), North Kazakhstan (58\%) and Kyzylorda (57\%).

Schools in Kazakhstan reflect the rich diversity existing in the country in terms of ethnicity, religion and language. The education system caters to students from 23 different ethnicities. Ethnic Kazakhs comprise $73 \%$ of students, ethnic Russians 14\%, and ethnic Uzbeks 4\%. Other minority groups reflect the movements during the Soviet period and include: Uighurs (1.5\%), Ukrainians (1.3\%) and Germans (1.0\%) (IAC, 2014). While secularity is enshrined in the constitution, Kazakhstan is predominantly Muslim (70\%), with around one quarter of the population declaring itself Christian (26\%) and 3.5\% indicating "other" or no religious affiliation (OECD, 2014a).

Students may study in one of the two official languages (Kazakh and Russian) or in other minority languages. Kazakh is considered the language of the Republic; and according to the 2009 census, it is understood by two thirds of the population. Russian is considered the language of inter-ethnic communication as it is understood by virtually everyone ( $94 \%$ of the population). English is understood by $15.4 \%$ of the population. The positive discrimination of the Kazakh language to strengthen national identity and to affirm it as the primary language of communication has translated into a growing 
number of schools using Kazakh as the language of instruction. In 2012, the language of instruction in most of the schools was Kazakh (3 819 schools), followed by Russian (1 394), Uzbek (60), Uighur (14), and Tajik (2) (IAC, 2014). About 2113 schools offered more than one language of instruction.

Education in Kazakhstan is divided into pre-primary education, school education (including primary, lower secondary and upper general or vocational secondary education), post-secondary and tertiary education (see the structure of the education system in table 1). School education is the term used in this report to refer to primary (grades 1-4), lower secondary (grades 5-9) and upper secondary education (grades 10, 11 and 12). These levels of education, as well as the two final years of pre-primary education, are compulsory and provided free of charge in public institutions.

Kazakhstan's level of educational attainment is comparatively high, approaching average levels of OECD countries. Of the adult population aged 25 and above, approximately $40 \%$ have upper secondary education as their highest level of attainment, $30 \%$ have a post-secondary degree and $25 \%$ have completed higher education.

\section{Main Institutions and Underlying Principles}

Kazakhstan's central government plays a very important role in the country's education and training system:

The Executive Office of the President defines key education strategies and develops major initiatives such as the network of Nazarbayev Intellectual Schools that cater to gifted students. The Office also monitors progress towards the objectives that are laid out in education strategies.
The Ministry of Education and Science of the Republic of Kazakhstan (MESRK) manages, implements and monitors work in education, science, protection of children's rights and youth policy. The MESRK is mandated to: define and execute educational policy; draft regulations with regards to funding education; prepare educational standards and curricula; organise and implement assessment systems; set requirements for teacher education; support the educational process in Kazakh language; and sign international agreements on education.

The MESRK has several subordinate organisations that operate in specific areas (e.g. quality assurance, statistics or managing international projects). For instance, the Information Analytic Center provides analytical support for the MESRK and is responsible for a variety of things, such as the Ministry's international projects (including reviews of the education system like this one). The National Center for Professional Development (ORLEU) provides a second example. It is responsible for the design and provision of professional development opportunities for teachers and school leaders.

The MESRK reports to the Executive Office of the President, is assessed by the Ministry of National Economy of the Republic of Kazakhstan (MNERK) for performance, and is monitored by the Ministry of Finance on the execution of its budget.

The underlying principles of Kazakhstan's education system are defined by the Constitution of the Republic of Kazakhstan (1995) and the Law on Education (2007). Among its main provisions, the Law on Education (2007) determines the objectives and principles of education, outlines the educational administrative structure and stipulates different administrative and financial aspects of education institutions' operations.

Table 1. Modern education system in Kazakhstan

\begin{tabular}{|c|c|c|c|c|c|}
\hline Education & School/Level & Grades & Age & Years & Notes \\
\hline Primary & Primary school & $1-4$ & $6-10$ & 4 & \\
\hline Middle & Middle school & $5-9$ & $10-15$ & 5 & General School, Gymnasium \\
\hline Secondary & Secondary school & $10-11$ & $15-17$ & 2 & $\begin{array}{l}\text { Secondary School, Lyceum, Gymnasium. Certificate/diploma } \\
\text { awarded: Atestat o Srednem Obrazovanii (Certificate of Complete } \\
\text { Secondary Education) }\end{array}$ \\
\hline Vocational & $\begin{array}{l}\text { Professional Lyceum, } \\
\text { Vocational school }\end{array}$ & $10-11$ & $15-17$ & 2 & $\begin{array}{l}\text { Certificate/diploma awarded: Diplom o Srednem Spetsialnom } \\
\text { Obrazovanii (Diploma of Secondary Vocational Education) }\end{array}$ \\
\hline Vocational & $\begin{array}{l}\text { Professional college, } \\
\text { vocational school }\end{array}$ & 10 & $15-19$ & 4 & $\begin{array}{l}\text { Certificate/diploma awarded: Diplom o Srednem Spetsialnom } \\
\text { Obrazovanii (Diploma of Secondary Vocational Education) }\end{array}$ \\
\hline Tertiary & $\begin{array}{l}\text { Diploma of specialist, } \\
\text { Bachelor }\end{array}$ & & & 4 & \\
\hline Tertiary & Master's & & & 2 & 2 years of study after Bachelor's degree program. \\
\hline Tertiary & $\mathrm{PhD}$, Doctorate & & & $3-15$ & $\begin{array}{l}\text { (Doktoratura) Kandidat Nauk (Candidate of Sciences) program } \\
\text { normally lasts for three years. Doctor Nauk (Doctor of Science) } \\
\text { program duration is not fixed (usually from } 5 \text { to } 15 \text { years). Doctor } \\
\text { of Science academic degree is a highest degree awarded after the } \\
\text { public defense of a dissertation considering also publications on } \\
\text { research work in scientific magazines. It does not always have an } \\
\text { equivalent in other countries. }\end{array}$ \\
\hline
\end{tabular}


Kazakhstan has formulated the goal of improving the quality of its education system, with international standards and practices serving as key points of reference. Building on the State Programme for Education Development in the Republic of Kazakhstan 2011-2020 (SPED), the updated State Programme for Education and Science Development 2016-2019 (SPESD) for 2016-19 lays out the current strategy for the education sector. The SPED identifies priorities, targets, and indicators to be achieved by 2020 from preschool to higher education.

At the level of primary and secondary education, key policy objectives include: developing new mechanisms of education financing such as per capita financing; providing education staff with more preparation, support and incentives; improving students' assessment methods; transitioning to a 12-year education model; updating curricula; and developing inclusive education with supports for low-performing students.

At the higher education level, the primary objectives of the SPED include: equipping students with skills more relevant to the labour market; integrating Kazakhstan more fully into the European Higher Education Area; bolstering synergies between education, science and industry; stimulating the commercialisation of research; fostering national identity; and encouraging active citizenship and social responsibility.

\section{Primary and Secondary Education}

In Kazakhstan, primary education is compulsory and spans the first four years of schooling. Children typically enrol at age seven, but six-year-olds can be admitted through an entrance exam. Secondary education has two levels: the basic lower level covers grades 5 through 9 and the general or vocational upper secondary level covers grades 10-11. A small minority of schools also have a grade 12 (e.g. the Nazarbayev Intellectual Schools) (see table 1).

The net enrolment rate for primary and lower secondary education (ages 5-14) is $99 \%$, and for upper secondary education (ages 15-19) it stands at $86 \%$. The enrolment rates of boys and girls are similar to each other. The most gifted students can attend the Nazarbayev Intellectual Schools: $0.4 \%$ of the total general secondary student population is enrolled at these special schools, which receive much more funding than mainstream schools (OECD and the World Bank, 2015).

Upon completion of the upper secondary level, students can enter technical vocational schools (colleges) or higher education institutions.

\section{Technical and Vocational Education}

Students can choose to enter vocational education and training (VET) institutions at upper secondary level (currently after 9th grade) or after upper secondary schooling (currently after 11th grade) (OECD, 2013a).

Since 2012, both kinds of institutions are referred to as "colleges". In 2013, Kazakhstan had a total of 888 VET institutions and the enrolment rate in 2015 was $16.1 \%$. There has been a decrease over the past years in the number of students enrolling in VET, although the government recently announced measures to encourage enrolment through a free tuition scheme. There are also concerns about poor co-ordination and interaction between VET schools and employers, and about poor quality assessment and certification processes (Álvarez-Galván, 2014).

\section{Higher Education}

In 2015, Kazakhstan had a total of 125 higher education institutions. This represents a significant decline from more than 180 institutions that were operating in 2000. Like many post-Soviet economies, Kazakhstan saw rapid growth in the number of private providers in the 1990s in response to high student demand. Over the past several years, Kazakhstan has been seeking to reduce this number (a process, known as "optimisation", which has led to mergers and sometimes closure of institutions).

In 2015, Kazakhstan's network of higher education institutions included 64 private institutions (including 10 joint-stock companies or "JSCs"4) and 61 public institutions. Of these institutions, 85 operate as universities, 21 as academies, 18 as institutes and one as a conservatory. These distinctions are made as part of institutional licensing procedures, and are based on a variety of factors including the number of graduate programmes, the institution's research profile, and its certifications and accreditations. There is one autonomous university in Kazakhstan: President Nazarbayev established Nazarbayev University in 2010, directing it to become a world-class university with a strong research programme (JSC Information-Analytic Center, 2015).

As we see from the background to the study, there is a national mandate for Trilingual Education in Kazakhstan for 12 years. The main strategic state programs for development of Kazakhstan, including the State Programme of Education Development for 2011-2020 (2010), the State Programme for Development of Education and Science for 2016-2019 (2016), National Plan "100 Concrete Steps" (2015), and Road Map for Trilingual Education (2015), were launched to implement trilingual education policy in the country. Despite this national mandate, there is a lack of clear and explicit guidelines of the implementation for educational institutions (Iyldyz, 2017). Nevertheless, with no national guidelines, schools are interpreting and implementing trilingual policy based on various understandings and to varying degree of success. For instance, in 2007, 31 Kazakhstani schools were offering trilingual education for gifted children, and by 2020 the number of these schools was planned to increase up to 700 (Mehisto, Kambatyrova, \& Nurseitova, 2014).

As of the end of 2015, the Kazakhstan Ministry of 
Education and Science had developed a Roadmap of Trilingual Education Development for 2015-2020 to guide the transition to trilingual education. The main goal of the project was to systematically implement trilingual education at every level of education in the Republic of Kazakhstan.

Like many other post-Soviet countries, Kazakhstan conducted a number of reforms in all areas of the state while transferring to a market economy and global competitive system. The Education Sector in Kazakhstan also conducts several reforms. Some of them were successful and some failed. The idea of a "trilingual language" was presented by President N.A. Nazarbayev for the first time at the 12th Congress of the Assembly of the Peoples of Kazakhstan, which was held in October 2006. In his speech, Nazarbayev said: "The time has come to create a special program for deepening the intensive training of English in all of our general schools and universities, and in 2007 we proposed a phased implementation of a cultural project called "Trilingualism" (Nazarbayev 2006). In November 2015, a road map was approved for the development of trilingual education for 2015-2020 [ZAKON 2015]. In this regard, in 2018-2019 academic year, Kazakh schools will be translated into a triple-linguistic system. And in 2023 the transition to this system will be completed. Nowadays multilingualism has many advantages and benefits, but there are costs associated with speaking multiple languages (Taomei Guo 2013).

Modern globalization is characterized by the exchange of free information between countries and focus on overall development. Moreover, as our Mukhtar Auezov said: "The people with the people, a man with a man are united by knowledge." One of the most important needs of our young Kazakh people is to become world leaders. The reason is that all the news and discoveries of science in the world, are mostly written in English. For example, international research and knowledge in the field of biology and medicine are mainly published in English press. Mr. Nazarbayev reported this at the third meeting of education and science workers: "The need for English today is a worldwide necessity" (Nazarbayev 2004).

The practice of teaching in English in the country began in the last decade. However, more attention is paid since 2015 , as mentioned above. With statistical technique, some scientists had strived to assess the discriminating potential of the different variables with which we have carried out their investigation in the bilingual and non-bilingual groups in CLIL education (María Luisa Pérez Cañado 2018). The trilingual boy from ages 3 years and a half to 5 years and a half and primary school the developing language systems was studying for early bilinguals and trilinguals (Maria-Pilar Safont-Jordà 2013., Gregory J.2012., Timothy P. Williams 2017).

One of the first schools that initiated the trilingual pilot study reform was our school - the Republic of Kazakhstan, the Almaty region, Talgar. It is the №8 Yuriy Gagarin talent training trilingual education special gymnasium, where about 500 students are studying, and about 100 teachers are teaching. The school is well organized in administrative and educational fields. Teamwork is good. Thanks to the high quality of teaching and learning, students have an excellent learning environment. The teaching of biology in English was based on the methods of "The Methodology of Teaching Biology" course of the Department of Biophysics and Biomedicine of the al-Farabi Kazakh National University, which were developed and coordinated by professors and lecturers of this university.

\section{Materials and Methods}

№8 Yuriy Gagarin talent training trilingual education special gymnasium, Talgar city, Almaty region, Republic of Kazakhstan, biology in English was taught once a week as an elective discipline in classes $8 \mathrm{~A}, 9 \mathrm{~A}, 10 \mathrm{~A}, 11 \mathrm{~A}$ (Kazakh language classes). Based on the Cambridge preliminary English test for schools, the result of English language proficiency level showing as follow:

- Overall 17 students are in grade 8A. 7 students of the $8^{\text {th }}$ grade are CEFR A2, 4 students of $8^{\text {th }}$ grade are CEFR B1, 6 students of $8^{\text {th }}$ grade shows CEFR A1;

- Overall 21 students are in grade 9A. 10 students of the $9^{\text {th }}$ grade are CEFR B1, 3 students of the $9^{\text {th }}$ grade are CEFR B2, 5 students of $9^{\text {th }}$ grade shows CEFR A2, 3 students of the grade $9^{\text {th }}$ shows CEFR A1;

- Overall 16 students are in grade 10A. 11 students of the $10^{\text {th }}$ grade are CEFR B2, 4 students of the $10^{\text {th }}$ grade are CEFR B1, 1 student is CEFR A2;

- Overall 11 students are in grade 11A, 3 student of the $11^{\text {th }}$ grade are CEFR B1, 6 students of the $11^{\text {th }}$ grade are CEFR A2, and 2 students of the $11^{\text {th }}$ grade are CEFR A1.

In this article, to achieve comparative results in $8 \mathrm{~A}$ class (Zoology), 9A class (Human biology) 2 hours per week, 10A class (Cytology) and 11A class (Evolution) 4 hours per week where taught. And quantified quarterly testing results (2017-2018 academic year) are presented in this article. We used the Cambridge English test for school to determine the level of English of students.

The purpose for determining the level of English proficiency by this method was to find out which methods should be used to teach students biology in English.

During this academic year, the following methods of teaching students based on the level of proficiency in English and on the basis of biological knowledge were used in the educational process.

- Bilingual teaching methods. Due to the fact that most of the students did not speak English well, we used terms (terminology) in the Kazakh language (translation of terms, interpretation of complex 
biological mechanisms), most of which were taught in English. Additional biological texts in English were learned by heart.

- Content and Language-Integrated Learning (CLIL) teaching method when delivering social science subjects, such as Geography, History of Kazakhstan, Kazakhstan in the Modern World and Law Essentials in Kazakh as a second language of instruction. CLIL is successful in this educational area that's why we used it as an interactive teaching method in our lessons (Kakenov, R. 2017).

- Demonstrative methods of teaching. The method of demonstrative presentation of teaching methods, posters, and video clips was used (Ydyrys A. 2017).

- The practical method of training in the classroom was mainly using microscopes to examine the cytological preparations, various models and additional demonstrative experiments were used (Izbassarova and Zhumagulova 2016).

- The method of case study - discussion of the lesson, the search for additional sources of literature and conducting teamwork, the organization of debates on the topic of discussion of the lesson (Tormanov et al. 2014).

Materials used in training - computer, interactive whiteboards, posters, drugs, microscopes, samples of living organisms, etc.

The following textbooks and manuals were used to teach biology in English: Cambridge IGCSE biology (Mackean and Hayward 2014), K.Kelly macmillan vocabulary practice series - science, textbooks on biology for schools in Kazakh [ATAMURA 2016].

Types of assessment of the above training was conducted through methodological and educational methodological principles for the implementation of the system of criterial evaluation of educational achievements of students, presented by the National Academy of Education named after Altynsarin [IAC 2015].

Types of training assessment includes assessment of homework (written), assessment in the class (oral, test), quarterly evaluation (test tasks).

Evaluation of the above training was calculated using the following formula, and the average value was obtained. FE $=\mathrm{a}+\mathrm{b} / \mathrm{n} * 100 \%$, where ' $\mathrm{a}$ ' is the number of students with 5 points (A grade), ' $b$ ' the number of students with 4 points (B grade), $\mathrm{n}$ the total number of students, $\mathrm{FE}$ - formative evaluation.

\section{Results and Discussion}

When we started teaching biology in English in the 8th grade (1st quarter), most students could express their thoughts in English in plain language. Doing homework was not complete. Of course, $20-30 \%$ of students in the class improved their level of English in additional courses, understood the lesson well, and did their homework. At the same time, the low level of general biological knowledge of students in their native language makes it difficult for them to study this subject in English. In this regard, we changed the teaching methodology together with the methodologists involved in the teaching of biology at the Al-Farabi Kazakh National University. The lesson was based on basic biological terms (terminology), and the students compiled these terms (terminology) and translated them into a notebook, read and wrote sentences in the context of the book or from their thoughts on the topic of the lesson. Particular emphasis was placed on the basis of this methodology with the interest of students who again began to study biology in English, and the results of the third quarter increased (Figure 1).

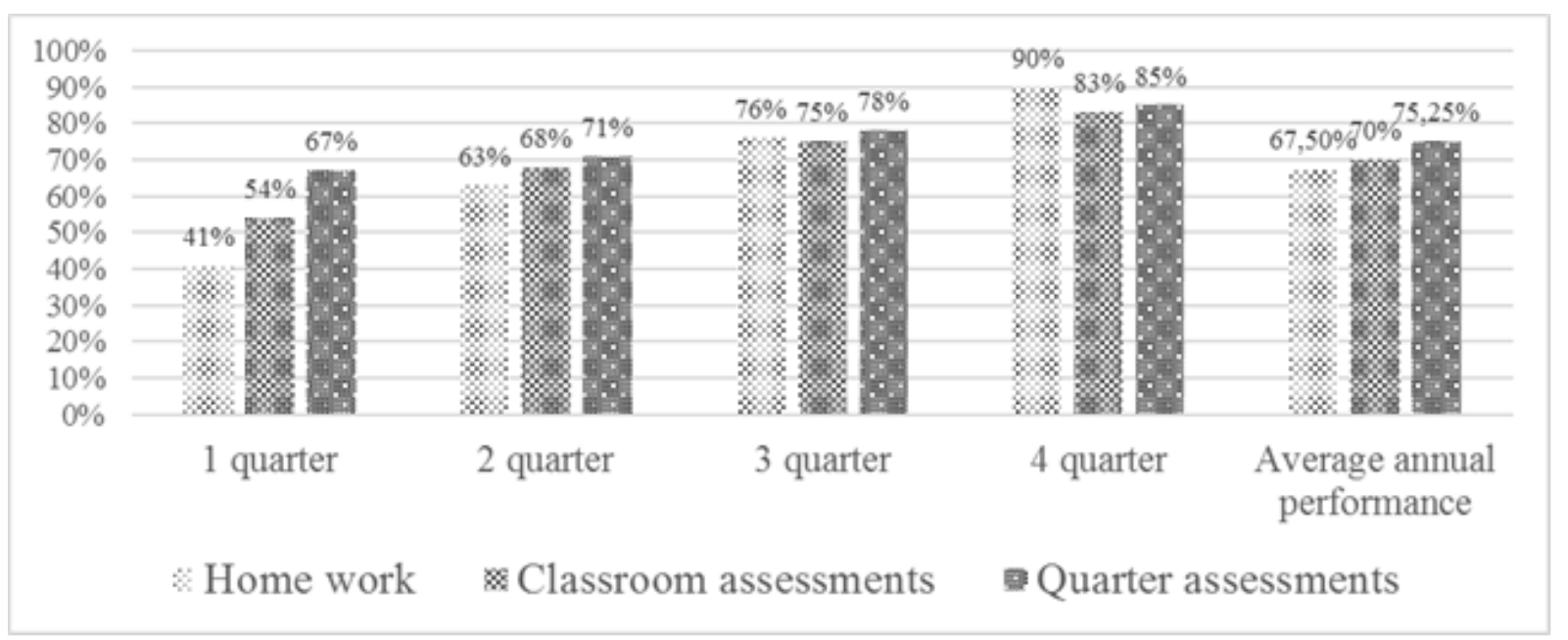

Figure 1. Results of the study of biology in English language of students of 8A class 2017-2018 academic year 
Figure 1 shows that in the first quarter the students did not have good command of English, that is why the writing of the homework at home and at the time of the completion of the material the oral answers were bad and their results were much higher quarterly because the quarterly examination was a test. Since the second quarter of this year, we used this method of teaching bilingualism (Kazakh, English) as the main method of instruction. Therefore, these results gradually increased quarterly.

The changes in the results of the study of biology for the students of the 9th grade were similar to the results of the 8A class, however, since the 9A students had a good command of English proficiency, therefore, various practical teaching methods based on the method of teaching in two languages were used (Figure 2).

In the first quarter, the grade 9A performance was low due to the lack of teaching aids and workbooks in English. This is typical for all classes. To solve this problem, we used the textbooks as additional material for preparing assignments and tests, and we translated some parts, printed and gave each student. Based on these efforts, the learning outcomes have increased.

Students of the 10th grade had a lower level of English, teaching them Kazakh, English, memorizing text and bilingual education, has given some results in the last quarters (figure 3 ).

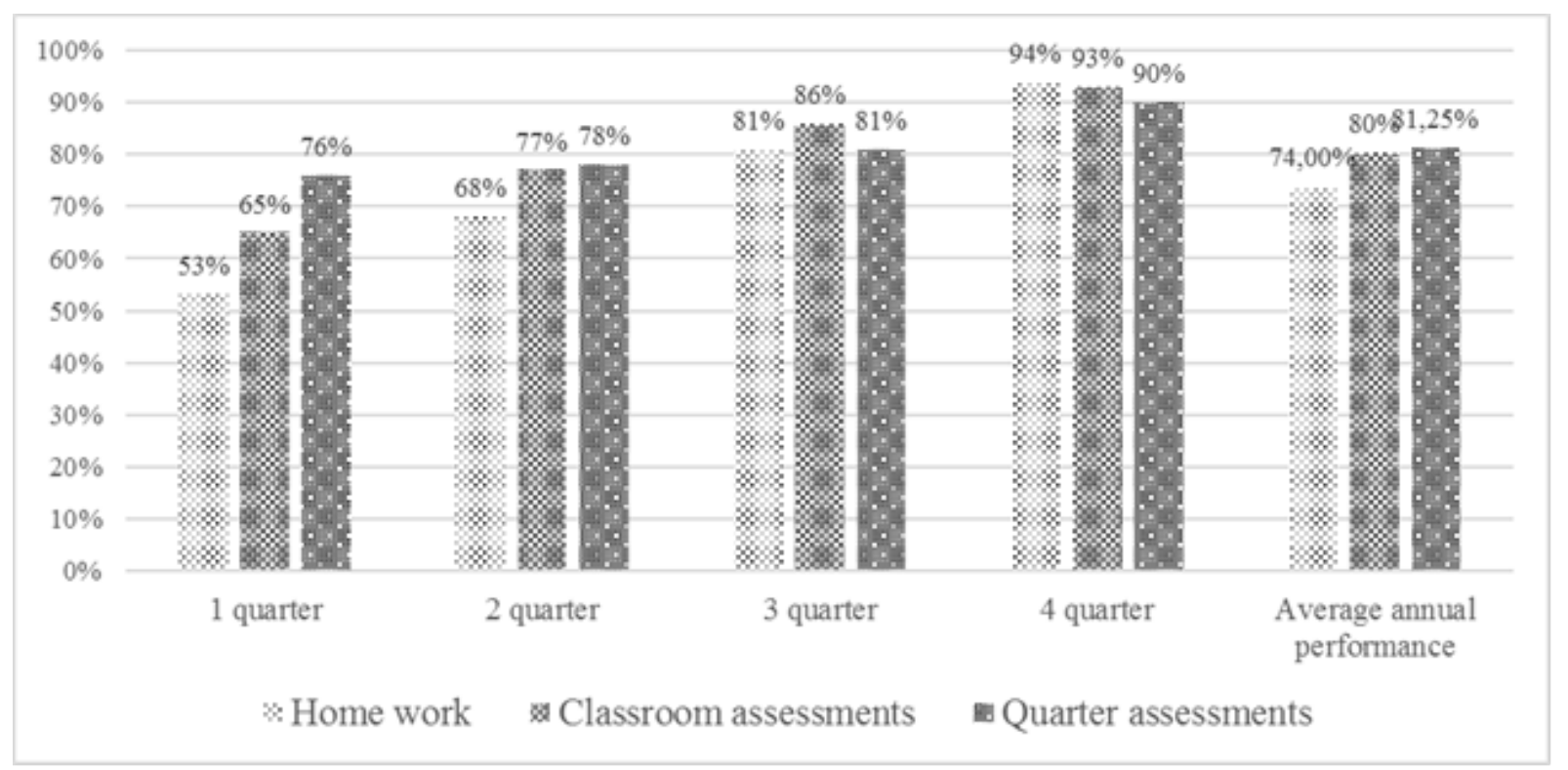

Figure 2. Results of the study of biology in English students 9A class 2017-2018 academic year

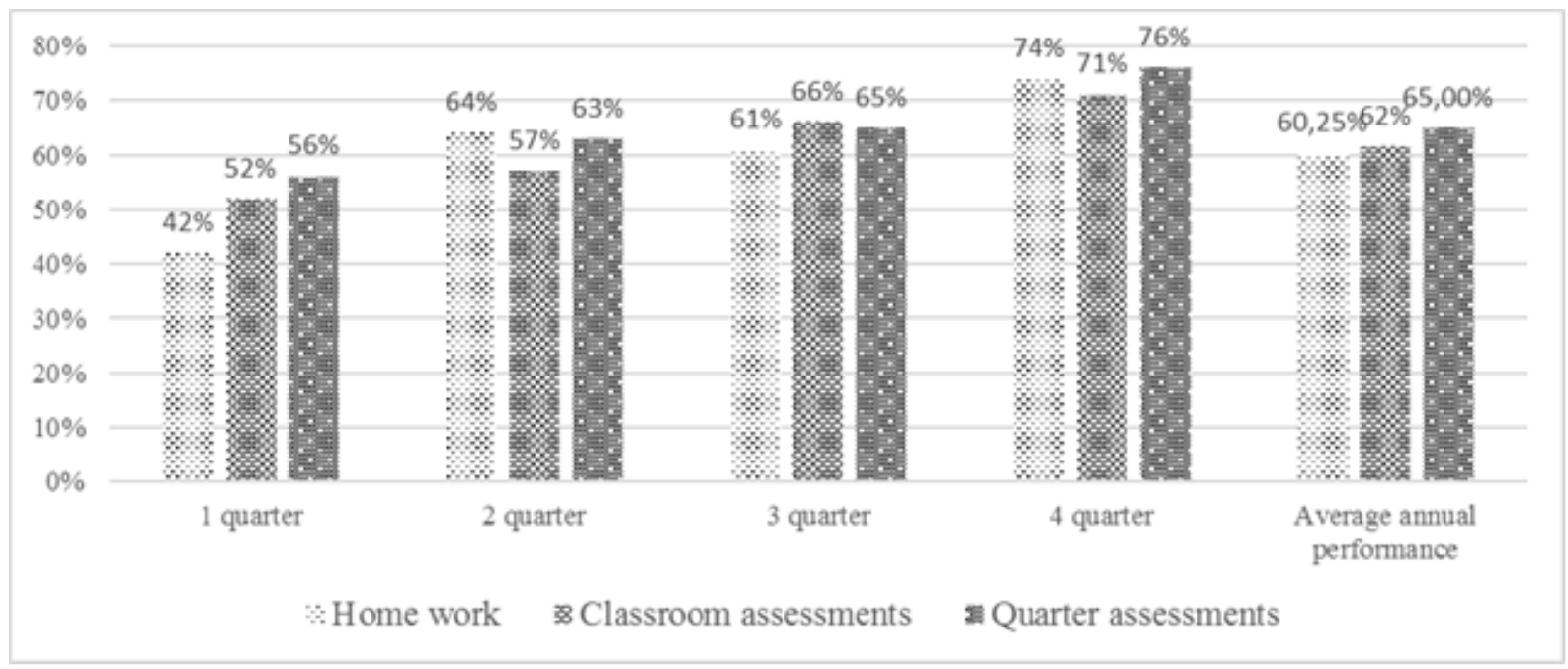

Figure 3. Results of the study of biology in English to students of 10A class 2017-2018 academic year 


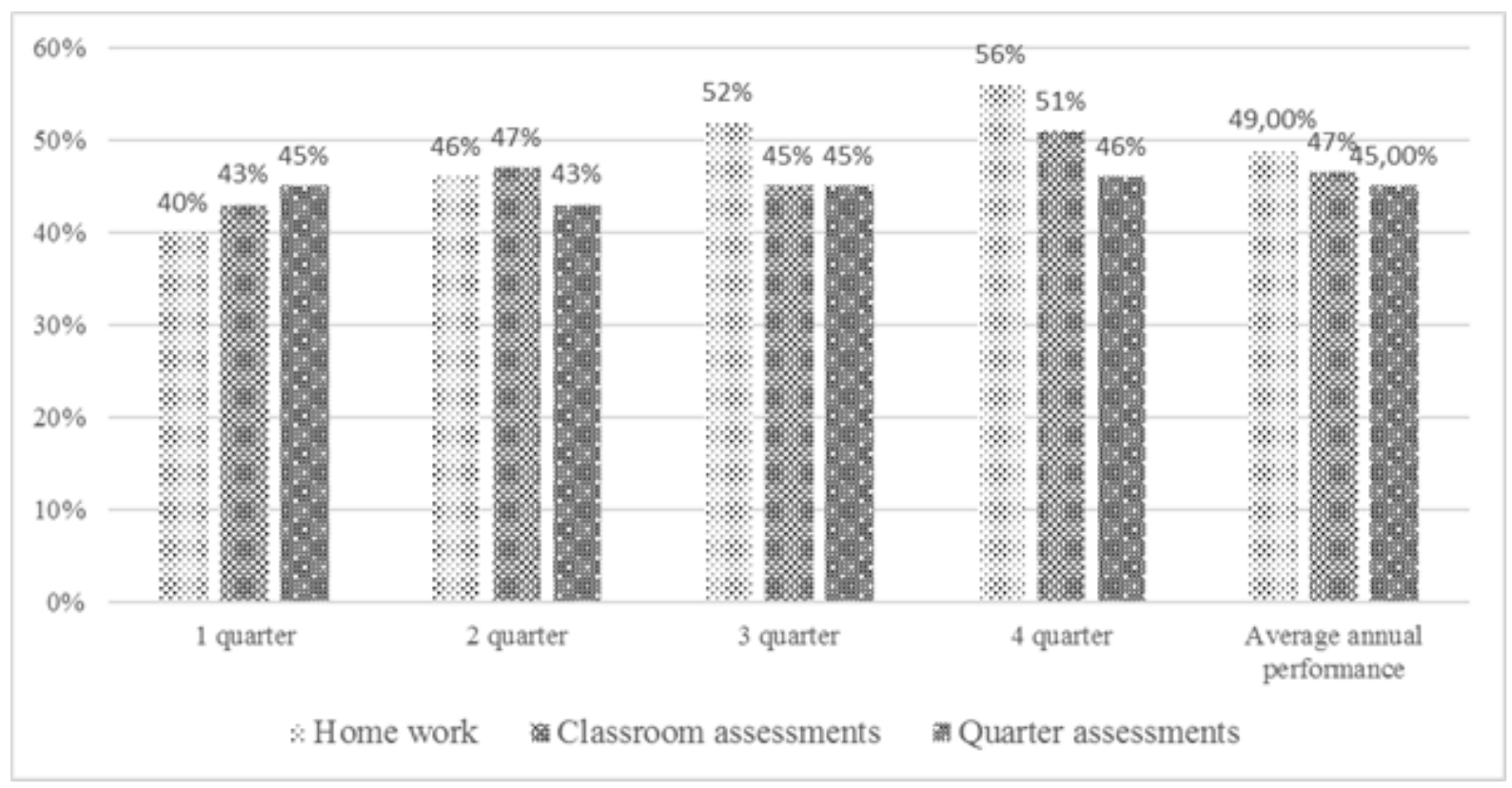

Figure 4. Results of the study of the biology in English to 11th grade students in the 2017-2018 academic year

However, since the students were preparing for a single national testing (state examination), less than half of them were interested in biology, because many of the students chose other subjects. Therefore, their results were very low.

Only 4 out of 11 students in grade 11 chose biology and chemistry as a subject for Unified National Testing (the high school entry examination in Kazakhstan). The results of the general class on biology were low.

Since (Figure 4) these are the results of 4 students who received over $90 \%$ in tests, however, only $40 \%$ when recalculated for the overall performance of the class. The remaining students did not want to waste their time on other subjects that did not interest them. Basically, the teaching of biology in English was conducted mainly by the method of random research and test tasks.

The study of natural sciences in Kazakhstan is connected, first of all, with the general level of knowledge of English among students. The move to Kazakh as the main communicative language in Kazakhstan has been on the government's agenda since the independence of the country in 1991 (Mehisto et al., 2014). As the subject teaching in Kazakh language in schools does not provide enough exposure to the language features in order to attain high proficiency language level, CLIL is seen as an effective approach to support this initiative. This is especially relevant as NIS is working to implement CLIL in all secondary schools across Kazakhstan by 2019 (MES, 2016).

The second problem is the use of teaching methods and teaching materials, the use of international textbooks at the same time as domestic (Kazakhstan) teaching aids, as we have shown in our practice in the use of textbooks, the use of practical tools, and the use of textbooks on biology.
Although the textbooks "Zambak" (printed in Turkey) are widely used today, as noted by the students, the textbook is difficult to write, and it is difficult to understand, and the language of the Cambridge IGCSE biology textbook is easy, simple and more interesting. Because "Zambak" series are just recommended course book by science and educational minister of republic of Kazakhstan, not the real official course book that we use.

The third issue is the teacher's problem, which, as mentioned above, the teachers of the natural sciences should be able to use the additional resources available to them, and be able to share these resources with the students. And more importantly, the teacher should be fully aware of his or her field and related subjects. For example, a teacher who teaches English in Kazakh classes must master the subject in Kazakh (and Russian). Because students do not fully speak English, the instructor must translate the complex parts of the subject into another language and translate the material. This means that in addition to providing quality education, it is necessary to create students' thinking in their own language.

The fourth question is the students' interest in biology. To be honest, this is a serious problem for classes 10 and 11 (Figure 3, Figure 4), because all students who choose biology and chemistry do not study this subject because they are preparing for UNT (the high school entry examination in Kazakhstan). And we used several ways to expand students' interest. First, make the lesson easier, easier to explain the use of innovative teaching methods. Fifth, it is important to emphasize the importance of the English language in general, as well as for people who have been successful (especially Kazakh scientists abroad). Sixth, the explanation of modern achievements of biology, their significance in human life and other disciplines. 


\section{Conclusions}

In the end, we cannot say that all students will speak English in the coming years and freely exchange information in this language. However, the teaching of natural sciences in English is an excellent opportunity for students to become a future specialist and to get a better job. This is the basis of the quality of human capital, and the competitiveness of the country. Here are a few ways to solve it, depending on the above problems:

- Schools need enough English textbooks, additional materials and vocabularies that help ensure the quality of their education in Kazakh, Russian and English. International textbooks and biological materials should also be available.

- To teach science in English, you need to have extra hours.

- Students should have quality English language courses at school, and students should be able to fully understand the life science.

- Teaching of subjects of natural sciences in English should be provided with additional material support and modern technologies.

- The most important, teachers teaching natural sciences in English should be able to choose the best and most effective methods of teaching in their field.

\section{REFERENCES}

[1] A joint order of the Acting President. Minister of Education and Science of the Republic of Kazakhstan dated November 5, 2015 № 622, Minister of Culture and Sports of the Republic of Kazakhstan from November 9, 2015 № 344 and the Minister for Investment and Development of the Republic of Kazakhstan dated November 13, 2015 № 1066. On approval of the Roadmap development of trilingual education for 2015-2020 https: //online.zakon.kz/Documen $\mathrm{t} /$ ?doc_id $=35182262 \#$ pos $=2 ;-91$

[2] Álvarez-Galván, J. (2014), A Skills beyond School Review of Kazakhstan, OECD Reviews of Vocational Education and Training, OECD Publishing, Paris, http://dx.doi.org/10.1787/9789264221826-en.

[3] Gregory J.Poarcha, Janet G.van Hellba 2012. Executive functions and inhibitory control in multilingual children: Evidence from second-language learners, bilinguals, and trilinguals. Journal of Experimental Child Psychology. Volume 113, Issue 4, December 2012, Pages 535-551. DOI: 10.1016/j.jecp.2012.06.013

[4] http://atamura.kz/?product=biologiya-9-sy-ny-p-o-uly 2016

[5] Iyldyz, L. (2017). Trilingual education policy in secondary schools in Kazakhstan: Teachers' beliefs and classroom practices (Unpublished doctoral dissertation). Nazarbayev University, Astana.

[6] Information-Analytic Center (IAC) (2014), OECD Review of Policies to Improve the Effectiveness of Resource Use in Schools: Country Background Report for Kazakhstan, Information-Analytic Center of the Ministry of Education and Science of the Republic of Kazakhstan, Astana, www.oecd.org/edu/school/ schoolresourcesreview.htm.

[7] Izbassarova R.Sh., Zhumagulova K.A. 2016. Textbook "Methodology of teaching biology" For students on specialty "Biology" - Almaty

[8] JSC Information-Analytic Center (2015), "Country Background Report", prepared for the OECD follow-up review of higher education policy in Kazakhstan, JSC Information-Analytic Center, Ministry of Education and Science of the Republic of Kazakhstan, Astana.

[9] Kakenov, R. (2017). Teachers' experiences of using CLIL in Kazakh language classrooms. NUGSE Research in Education, 2(2), 21-29. Retrieved from nugserie.nu.edu.kz

[10] María Luisa Pérez Cañado 2018. The effects of CLIL on L1 and content learning: Updated empirical evidence from monolingual contexts. Learning and Instruction 57 (2018) 18-33. DOI: 10.1016/j.learninstruc.2017.12.002

[11] Mackean D.G. and Dave Hayward. 2014. "Cambridge IGCSE, Biology" third edition, Hodder Education.

[12] Maria-Pilar Safont-Jordà 2013. Early stages of trilingual pragmatic development. A longitudinal study of requests in Catalan, Spanish and English. Journal of Pragmatics 59 (2013) 68 - 80. DOI: 10.1016/j.pragma.2013.01.007

[13] MES (Ministry of Education and Science of Kazakhstan). (2016). Doklad ministra obrazovaniya i nauki na otchetnoy vstreche s predstavitelyami [The report of the Minister of Education and Science of Kazakhstan to the community representatives]. Retrieved on May 01, 2016 from http://edu.gov.kz/ru/news/doklad-ministra-obrazovaniya-in auki-erlana-sagadieva-na-otchetnoy-vstreche-s-predstavitel yami

[14] Methodological and educational-methodological bases of the system of criteria-based assessment of educational achievements of students. 2015. Methodological tool. -Astana: National Academy of Education named after Altynsarin.

[15] Mehisto, P., Kambatyrova, A., \& Nurseitova, K. (2014). Three in one? Trilingualism in education policy and practice. In D. Bridges (Ed.), Educational reform and internationalisation: The case of school reform in Kazakhstan (pp. 152-177). Cambridge University Press.

[16] OECD (2013a), PISA 2012 Results: What Makes Schools Successful (Volume IV): Resources, Policies and Practices, PISA, OECD Publishing, Paris, http://dx.doi.org/10.1787/9789264201156-en.

[17] OECD (2014a), Reviews of National Policies for Education: Secondary Education in Kazakhstan, OECD Publishing, Paris, http://dx.doi.org/10.1787/9789264205208-en.

[18] Speech of the President of the Republic of Kazakhstan N. A. Nazarbayev at the III Congress of Education and Science Workers of the Republic of Kazakhstan "Updated country quality education". 2004.http://online.zakon.kz/Document/ ?doc_id=1050840

[19] Speech of the President of the Republic of Kazakhstan 
Nursultan Nazarbayev at the XII session of the Assembly of Peoples of Kazakhstan (Astana, October 24, 2006) https://www.zakon.kz/77635-vystuplenie-prezidenta-respu bliki.html

[20] Taomei Guo, Fengyang Ma, Fengqin Liu 2013. An ERP study of inhibition of non-target languages in trilingual word production. Brain \& Language 127 (2013) 12-20.

[21] Tormanov N.T., Ursheeva B.I. 2014. Guideline of teaching-methodological complex from innovative methods of teaching biology., Almaty, Kazakh University.

[22] Timothy P. Williams 2017. The Political Economy of Primary Education: Lessons from Rwanda. World Development, Volume 96, August 2017, Pages 550-561 DOI: 10.1016/j.bandl.2013.07.009

[23] Ydyrys A.Y. 2017. Methods of teaching biology: educational-methodical manual / - Almaty: Qazaq University. 